International Journal of Current Advanced Research

ISSN: O: 2319-6475, ISSN: P: 2319 - 6505, Impact Factor: SJIF: 5.995

Available Online at www.journalijcar.org

Volume 6; Issue 3; March 2017; Page No. 2886-2889

DOI: http://dx.doi.org/10.24327/ijcar.2017.2889.0133

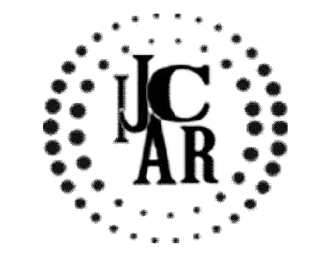

Research Article

\title{
EFFECTIVENESS OF PAPERS 53 APP IN TEACHING METHODOLOGY
}

\author{
Kadambari Sriram and Brundha M.P
}

Saveetha Dental College and Hospitals, Saveetha University, 162. P.H.Road, Chennai 600 077, India

\begin{tabular}{l}
\hline A R T I C L E I N F O \\
Article History: \\
Received $20^{\text {th }}$ December, 2016 \\
Received in revised form $24^{\text {th }}$ January, 2017 \\
Accepted $4^{\text {th }}$ February, 2017 \\
Published online $28^{\text {th }}$ March, 2017 \\
\end{tabular}

Key words:

Audio-visual aids, Apps, Video-learning, teaching methodology, Education

\begin{abstract}
A B S T R A C T
Objective: To study the uses of Papers 53 app as a means of teaching.

Methods: 50 participants were asked to study the written material and 50 participants were asked to listen to the video. A self formulated questionnaire on the same topic was distributed amongst the students to test their learning and compare the efficacy of the two methods. Friedman's test was applied for statistical analysis.

Results: Percentage of respondents answering the test correctly with the text learning method is $36.2 \%$, while $36.6 \%$ of the respondents answered correctly with the video learning method.

The Friedman test has indicated on analysis of the differences in the medians of both methods, that there is no significant difference with a $\mathrm{p}$ value of 0.077 .

Conclusion: Audio-visual methods play a dynamic role in the teaching learning process at the University level. It has been seen that these methods are as effective as the conventional teaching learning process using written material.
\end{abstract}

Copyright $\bigcirc 2017$ Kadambari Sriram and Brundha M.P. This is an open access article distributed under the Creative Commons Attribution License, which permits unrestricted use, distribution, and reproduction in any medium, provided the original work is properly cited.

\section{INTRODUCTION}

Education cultivates productive environments and relationships for learning. [1] Learning being both a process and an outcome, in order to acquire new knowledge, [2] students,[3] need to be able to make sense of new information. This can be ensured by learning strategies or few technical methods [4] and teacher intervention and instruction that models the use of learning strategies and helps make new information more accessible to students. Especially concerning with the medical education, the curriculum seems to be getting more and more advanced. Since filmstrips were first studied during World War II as a training tool for soldiers (Hovland, Lumsdaine\& Sheffield, 1949), educators have recognized the power of audio-visual materials to capture the attention of learners, increase their motivation and enhance their learning experience.[5]The use of Audio-visual methods of teaching is gaining importance in the field of education. Education, being a process of knowledge transfer always has advances which are generally on par with the discovery of newer technologies. Currently, most of the education process has shifted away from the conventional black board methods towards the usage of more student friendly technologies.[6] Audio- Visual aids are those instructional devices which are used in the classroom to encourage learning and make it easier and interesting.

\footnotetext{
*Corresponding author: Kadambari Sriram

Saveetha Dental College and Hospitals, Saveetha

University, 162. P.H.Road, Chennai 600 077, India
}

radio, television etc. called instructional aids.[7] Using A.V aids in teaching is one way to enhance lesson plans and give students additional ways to process subject information. [8] A.V aids are devices present unit of knowledge through auditory of visual stimuli both with a view to help learning. They concretize the knowledge to be presented and help in making learning experience ample real, living and vital. They supplement the work of the teacher and help in the study of the text books. [9] Apps are specialized programs for mobile devices which have many features including audio-visual functions. These attributes have also enabled apps to play a role in education. They are predominantly used as a means to create videos and animations to give an enhanced visual representation of study material. The Paper 53 app which was used in this research is compatible with IOS systems and combines both note-taking capacity long with drawing and editing existing images. The app was launched in March 2012 by FiftyThree.inc.

App-based video lectures have shown to improve student's learning output in various disciplines. However, most of the research has focused primarily on videos as adjutants to traditional lectures. [10]

Technology has been developing day to day which is highly useful in educational aspects for students like introducing iPad system without carrying heavy textbooks or notebooks, which cause lesser environmental effects. Whereas iPad are environmentally beneficial still it carries a huge aspect on optic defects, expense, infrastructure, etc. 


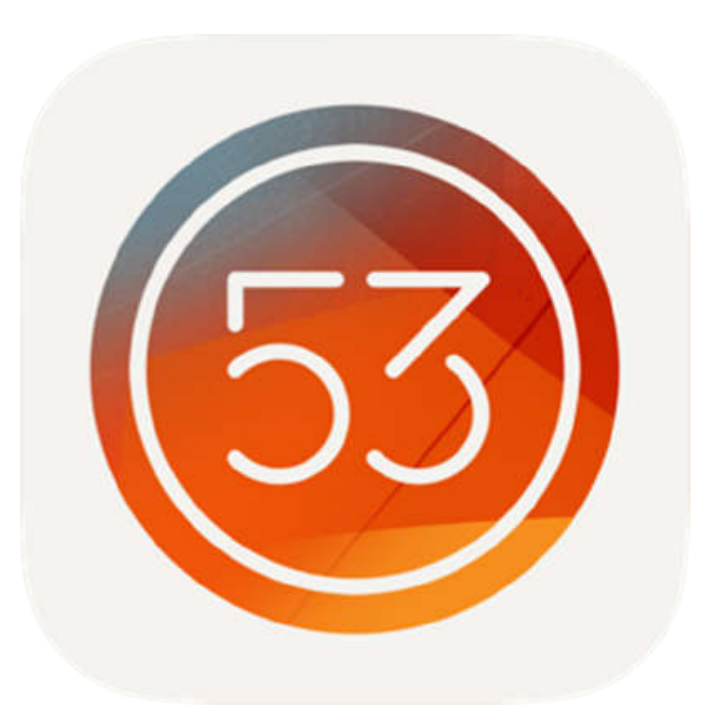

Both the conventional as well as app based systems have advantages and disadvantages and both the systems above provides students with opportunities to deepen their learning from different techniques.[11]
As there is growth in the available literatures on the usage of podcasts in education, there is mixed response on the acceptability of this mode of learning. [6] Video demonstration enhances the learning from a lecture and is considered to be one of the most standardized modes of instruction in recent times.[6] This study is a unique attempt to evaluate the learning outcomes when an entire lesson was covered as a video based lecture using apps. This study also aims to evaluate if there is any significant difference between performance of students using written material and students using audio-visual methods.

Audio-visual methods play a dynamic role in the teaching learning process at the University level.

\section{MATERIALS AND METHODS}

This was a blanket study and involved 100 participants who were second year undergraduate students in the BDS (Bachelor of Dental Surgery) course. A video was prepared using the Papers $53 \mathrm{App}$ as well as written material on the same topic from the curriculum.

\section{Chart 1. Performance in text based method}

Which giant cells are seen in mycobacterium induced granuloma

Which giant cells have horseshoe arrangement of nuclei?

In which condition is touton cell found?

Which is the condition in which reed sternberg cells are found?

Which giant cell is formed in inflammation when macrophages.

Which giant cell is derived from foam cells?

Which is a mycobacterium induced giant cell?

What is an example of physiologic giant cell

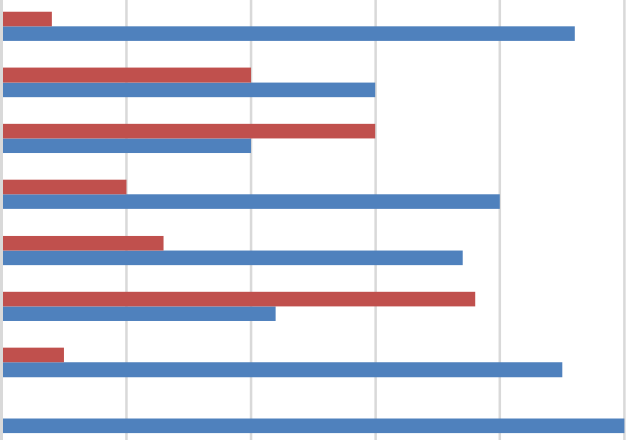

$\begin{array}{llllll}0 & 10 & 20 & 30 & 40 & 50\end{array}$

Wrong Answer $\quad$ Right answer

\section{Chart 2. Performance in Video-based method}

Which giant cells are seen in mycobacterium induced granuloma

Which giant cells have horseshoe arrangement of nuclei?

In which condition is touton cell found?

Which is the condition in which reed sternberg cells are found?

Which giant cell is formed in inflammation when macrophages..

Which giant cell is derived from foam cells?

Which is a mycobacterium induced giant cell?

What is an example of physiologic giant cell

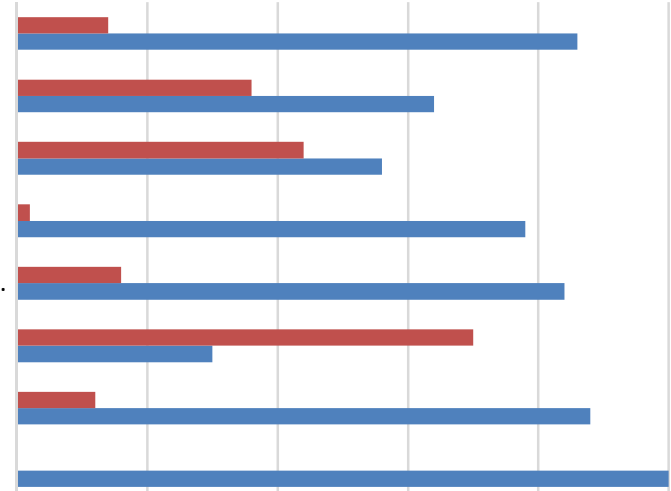
10 20 30 40 
50 participants were asked to study the written material and 50 participants were asked to listen to the video. A selfformulated questionnaire on the same topic was distributed amongst the students to test their learning and compare the efficacy of the two methods. Friedman's test was applied for statistical analysis using SPSS software.

\section{RESULTS}

Table 1 Results of students who studied the text material

\begin{tabular}{ccc}
\hline $\begin{array}{c}\text { Questions } \\
\text { Answered }\end{array}$ & $\begin{array}{c}\text { No. Of students } \\
\text { answering right }\end{array}$ & $\begin{array}{c}\text { No. Of students } \\
\text { answering wrong }\end{array}$ \\
\hline Q 1 & 50 & 0 \\
Q 2 & 44 & 6 \\
Q 3 & 15 & 35 \\
Q 4 & 42 & 8 \\
Q 5 & 39 & 1 \\
Q 6 & 28 & 22 \\
Q 7 & 32 & 18 \\
Q 8 & 43 & 7 \\
\hline
\end{tabular}

Table 2 Results of students who studied the video-based lecture

\begin{tabular}{ccc}
\hline $\begin{array}{c}\text { Questions } \\
\text { Answered }\end{array}$ & $\begin{array}{c}\text { No. answering } \\
\text { right }\end{array}$ & $\begin{array}{c}\text { No. answering } \\
\text { wrong }\end{array}$ \\
\hline Q 1 & 50 & 0 \\
Q 2 & 45 & 5 \\
Q 3 & 22 & 38 \\
Q 4 & 37 & 13 \\
Q 5 & 40 & 10 \\
Q 6 & 20 & 30 \\
Q 7 & 30 & 20 \\
Q 8 & 46 & 4 \\
\hline
\end{tabular}

\section{Analysis and interpretation}

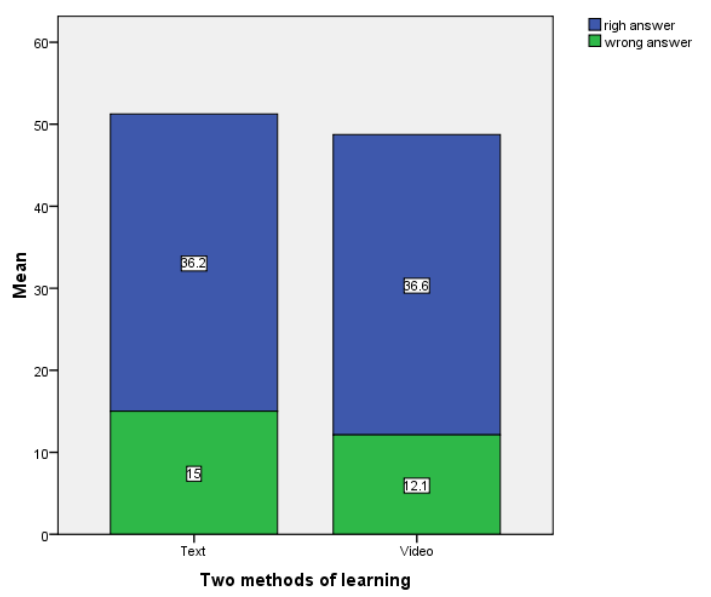

Figure 1 Stacked graph between text learning and video learning method

From the above diagram, the respondent who answered correctly with text learning method is $36.2 \%$ and the respondent who answered correctly with video learning method is $36.6 \%$. $15 \%$ of the respondent answered wrongly in text learning and only $12.1 \%$ are from video learning method. There is slight difference in learning with text and video method.

\section{Friedman Test}

Friedman test is a test for comparing three or more related samples and which makes no assumptions about the underlying distribution of the data. The data is set out in a table comparing rows and columns.

\section{Hypothesis}

$\mathrm{H}_{0}$ : There is no significance different between the learning with text and learning with video.

$\mathrm{H}_{1}$ : There is significance different between the learning with text and video.

\begin{tabular}{cc}
\hline \multicolumn{2}{c}{ Ranks } \\
\hline & Mean \\
& Rank \\
right_text & 3.06 \\
wrong_text & 2.19 \\
right_video & 3.06 \\
wrong_video & 1.69 \\
\hline
\end{tabular}

The Friedman test compares the mean ranks between the related groups and indicates how the groups differed. From the above mean rank table, learning with text method who says correct answer is 3.06 and learning with video method who says correct answer is 3.06 . So, there is no difference in the learning methods.

\begin{tabular}{cc}
\hline \multicolumn{2}{c}{ Test Statistics $^{\text {a }}$} \\
\hline N & 8 \\
Chi-Square & 6.846 \\
df & 3 \\
Asymp. Sig. & 0.077 \\
a. Friedman Test \\
\hline
\end{tabular}

The Friedman test, which evaluated differences in medians among two learning method, is insignificant $\chi^{2}(3, \mathrm{~N}=8)=$ $6.48, \mathrm{p}=0.077$. Which indicates that there are no significant difference among the two methods - Learning with text and learning with video.

\section{DISCUSSION}

This was a cross sectional blanket study to test the efficacy of the Paper 53 app as an education tool and its application in teaching methodology. Deal and Lazzari found no significant improvement on student grades [14] whereas McKinney found that students only benefitted from podcasts when they took notes and listened to the podcast many times [15].

This study has shown that the percentage of the respondents who have answered correctly through the method of text based learning is $36.2 \%$ which is very close to the percentage of respondents who answered correctly through the video based lecture which was $36.6 \%$. There is no significant difference between these values showing that the video based method seems to have equal efficacy as compared to text based learning.

The students in this study had also reported that the videos were also useful for quick revision during their examination preparation. This could be attributed to change in the trends and technology; where in today's students are more digitally fluent managing various electronic devices including iPods, iPads, cell phones, internet and televisions [16]. The students mainly use the video/audio pods for reviewing in future; the concepts presented in lectures that they had previously attended [17-18]. This could explain the better performance of the test group observed in this study. With respect to Dentistry, Brittan et al., has reported that video podcasts helped the students in revision more effectively than the textbook [19].

The Friedman test, which evaluated differences in medians among two learning method, showed insignificance $\chi^{2}(3, \mathrm{~N}=$ $8)=6.48, p=0.077$. This indicates that there is no significant 
difference among the two methods - Learning with text and learning with video.

Since there is no significant statistical difference in the mean undergraduate examination scores obtained by the students of both groups, the observed difference in the scores can only be attributed to the change in the teaching methodology. Fischer et al., had noted the advantages of audio and video podcasts in higher education. They observed that audio and video podcasts can "provide students with the ability to learn on demand based on their own learning styles" and can also provide a mechanism that motivates students to "actively engage in the course content" [19]. The difficulty of the questionnaire may have impacted the results of the study.

New technologies are already making their way into dental practice and have changed the traditional approaches to make the treatment easier, simpler, reducing patient's discomfort, for which education about newer technologies are necessary for undergraduate students.[20]

All the students in this study had no previous exposure or knowledge on the material covered in this course and hence, it could not have affected the results of this study.

\section{CONCLUSION}

Within the limits of this study it can be seen that Apps like the Paper 53 app and other audio-visual methods are as effective as traditional lectures and text based learning as there is no significant difference in the performance of students in both the methods. This is also indicates the major role apps can play in Education in the near future.

\section{References}

1. Daniel L. Schacter, Daniel T. Gilbert, Daniel M. Wegner (2011) [2009]. Psychology, 2nd edition. Worth Publishers. p. 264. ISBN 978-1-4292-3719-2.

2. Rules for the study of natural philosophy", Newton 1999, pp. 794-6, from the General Scholium, which follows Book 3, The System of the World.

3. Studentification: A Guide to Opportunities, Challenges and Practice

4. "Adaptive Learning Systems - National Institute of Standards andTechnology". Archived from the original on 16 September 2008. Retrieved August 17, 2008.

5. Hovland, C.I., Lumsdaine, A.A. \& Sheffield, F.D. (1949). Experiments on mass communication. Princeton, NJ: Princeton University Press.

6. Murthykumar K, Veeraiyan DN, Prasad P. Impact of Video Based Learning on the Perfomance of Post Graduate Students in Biostatistics: A Retrospective Study. Journal of clinical and diagnostic research: JCDR. 2015 Dec;9(12):ZC51.

7. Rather, A.R. (2004); Essentials Instructional Technology, published by Darya gaj New Delhi.
8. Kunari, C (2006); Methods of teaching educational Technology, New Delhi. Mohanty, J (2001); Educational Technology, Publish by Rajouri garden New Delhi.

9. Herder P, Subrahmanian E, Talukdar S, Turk AL, Westerberg A. The use of video-taped lectures and web-based communications in teaching: a distanceteaching and cross-Atlantic collaboration experiment. European Journal of Engineering Education. 2002;27(1):39-48.

10. Whatley J, Ahmad A. Using video to record summary lectures to aid students' revision. Interdisciplinary Journal of E-Learning and Learning Objects. 2007; 3(1):185-96.

11. Shyu HYC. Using video-based anchored instruction to enhance learning: Taiwan's experience. British Journal of Educational Technology. 2000; 31(1):57-69.

12. Thenmozhi MS. Educational Research-iPad System vs Textbook System. Research Journal of Pharmacy and Technology. 2015 Aug 28; 8(8).

13. Monisha K, Krishnamoorthy K. Study of Effective Methods of Learning and its Relation in Retaining Long Term Memory-A Questionnaire Based Study. Indian Journal of Applied Research. 2016 Jul 13;6(6).

14. Deal A. Podcasting: a teaching with technology white paper, Office of Technologyfor Education \&EberlyCenter for Teaching Excellence. Carnegie Mellon University, Jun07. pdf, [Accessed 4 October 2007]; 2007.

15. Lazzari M. Creative use of podcasting in higher education and its effect on competitive agency. Computers \& Education. 2009;52(1):27-34.

16. McKinney D, Dyck JL, Luber ES. iTunes University and the classroom: Can podcasts replace Professors? Computers \& education. 2009;52(3):617-23.

17. Brittain S, Glowacki P, Van Ittersum J, Johnson L. Podcasting lectures. Educausequarterly. 2006;(3):2431.

18. Fisher M, Baird DE. Making mLearning work: Utilizing mobile technology for active exploration, collaboration, assessment, and reflection in higher education. Journal of Educational Technology Systems. 2006;35(1):3-30.

19. Rasul S, Bukhsh Q, Batool S. A study to analyze the effectiveness of audio visual aids in teaching learning process at uvniversity level. Procedia-Social and Behavioral Sciences. 2011 Jan 1;28:78-81.

20. Jayashree RS, Kumar RA. Dental Laser Education And Knowledge Among Final Year Dental Students At Saveetha Dental College-A Questionnaire Study. International Journal. 2015;3(12):556-61.

\section{How to cite this article:}

Kadambari Sriram and Brundha M.P (2017) ' Effectiveness Of Papers 53 App In Teaching Methodology', International Journal of Current Advanced Research, 06(03), pp. 2886-2889.

DOI: http://dx.doi.org/10.24327/ijcar.2017.2889.0133 